\title{
ACTIVITATEA BIOLOGICA A TULPINILOR AUTOHTONE DE BACILLUS THURINGIENSIS IN COMBATEREA GÂNDACULUI DIN COLORADO
}

\author{
Zavtoni P., Zavtoni I.
}

Institutul de Genetică, Fiziologie și Protecție a Plantelor a Republicii Moldova 2060, str. Pădurii, 26/2, Chișinău. E-mail: pantelimonzavtoni@ rambler.ru

https://doi.org/10.53040/9789975347204.25

Abstract. Entomopathogenic bacterial biopreparations have an important role in controlling harmful insects in agriculture, giving the possibility not to use dangerous pesticides and environmental pollution to minimize soil degradation; beneficial bacteria turn plant residues into organic fertilizers. In 
the control, the development of larvae increased from $10^{9}$ to 221 larvae. And in the variant Bacillus thuringiensis $10^{7}$ before processing there were 141, 6 larvae and after processing it dropped to 80, 6 larvae.

Keywords: strains, ecology, bacteria, microorganisms, agriculture, soil, baculoviruses.

\section{Introducere}

Folosirea pe scară largă a pesticidelor in agricultură pe lângă aspectele pozitive a evidențiat și o serie de cazuri negative, cele mai importante fiind producerea de perturbări din biocenoză, prin distrugerea în masă a insectelor entomofage, apariția de forme rezistente la pesticide și tratamente duble la prelucrarea culturilor, la poluarea mediului și acumularea unor pesticide în produsele alimentare şi în final pesticidele utilizate în agricultură duc la degradarea solului și stocarea lor in diferite straturi ale pământului în adâncime.

În secolul XX a fost propusă o metodă de îmbunătățire a componenței microflorei solului prin introducerea în sol a microorganismelor benefice. A fost demonstrat că mai multe tulpini de bacterii contribuie esențial la dezvoltarea plantelor și totodată scade activitatea fitopatogenilor și dăunătorilor [4].

Solul conține mai multe categorii de microorganisme, care pot fi benefice în agricultură și structurii solului ca: baculovirusurile, bacteriile (B.thuringiensis, Azotobacter, Bacillus subtilis și alt.). Aplicarea biopreparatelor biologice în agricultură îndeplinesc un rol important în procesul de protejare a solului de diferite preparate chimice și în combaterea insectelor dăunătoare in agricultura ecologică . Biopreparatele au proprietatea de a nu polua și a nu degrada structura și componența solului. Biopreparatele baculovirale, bacteriene, micotice în protecția culturilor agricole atacă numai dăunătorii țintă, iar fauna utilă rămâne și lucrează mai departe pentru îmbunătăţirea și fertilizarea solului. De exemplu, entomofauna utilă ca râmele, entomofagii prădători a insectelor dăunătoare - Perilius bioculatus, Podizus maculiventris, bugurile - Damselbug (Nabis liniatus) care se hrănesc cu dăunătorii care dăunează la culturile de cartof, tomate, vinete, ardei și alte culturi. Acești entomofagi nu sunt atacați de biopreparatele baculovirale, bacteriene și alte preparate biologice la prelucrarea culturilor legumicole cu microorganisme în combaterea dăunătorilor. La rândul lor râmele rămân vii și joacă un rol foarte important pentru aerația și îmbogățirea solului.

Vizitând Institutul de Microbiologie Agricolă din Sankt-Petersburg - Pușkin Federația Rusă unde am făcut cunoștință cu colecția departamentală de microorganisme utile pentru scopuri agricole (VKSM, Sankt-Petersburg - Puşkin FR) unde sunt stocate bacterii benefice de Bacillus thuringiensis, care au fost studiate cultural-morfologic, fiziologic, biochimic, tehnologic, și alte proprietăți.

Una dintre prioritățile tulpinilor de colecție - Bacillus thuringiensis var. darmstadliensis (BtH10) № 25, care stă la baza biopreparatului Бацикол, şi are un efect specific asupra Coleopterelor și o activitate antifungică față de un număr de ciuperci patogene. Tulpina BtH10 № 25 depus în colecție este înregistrat cu numărul de înregistrare 01490 RCAM (număr de brevete 2514023,2014) [3].

Utilizarea preparatelor biologice în combaterea agenților patogeni duc la o fertilizare a solului și la dezvoltarea mai intensă a microorganismelor benefice în sol și a entomofagilor prădători ai dăunătorilor la culturile legumicole.

\section{Materiale și metode}

La cercetări s-au aplicat bacteriile de Bacillus thuringiensis din laboratorul Fitopatologie și Biotehnologie al Istitutului de Genetică, Fiziologie și Protecție a Plantelor. Pentru selectarea tulpinilor bacteriene cu acţiune insecticidă asupra dăunătorilor au fost 
utilizate culturi de Bacillus thuringiensis din colecţia institutului de microorganisme nepatogene şi alte tulpini izolate din larvele colectate în condiţii naturale a gândacului din Colorado. Microorganismele cercetate au fost insămânţate în cutii Petri pe diferite medii de cultură, pentru formarea coloniilor şi metaboliţilor, în trei repetiţii şi cultivate în condiţii optime pentru fiecare specie.

Titrul s-a determinat cu ajutorul camerei Goreaev.

Titrul a fost calculat după formula

$\mathrm{T}=25,10^{4} \times \mathrm{A} \times \mathrm{D}$,

A-numărul mediu de bacterii într-un pătrat mare

D-diluţii

T-titrul suspensiei bacteriene la $1 \mathrm{ml}$

Prelucrarea statistică a datelor se va efectua după metoda lui C.A. Gar [2].

Eficacitatea biologică a fost efectuată după formula:

A-B

$$
\mathrm{X}=\text {--------- X 100\% }
$$

A

unde X - activitatea biologică exprimată în procentul de mortalitate a insectelor.

A- larve până la prelucrare. B- larve după prelucrare.

\section{Rezultate și discuții}

Dezvoltarea larvelor de vârsta a 2-3 a gândacului (Leptinotarsa decemlineata) de prima și a doua generație în condiții de câmp la cultura de cartof, la o plantă revenea 0,5-7,6 larve.

Lotul experimental de cartof a fost prelucrat cu suspensie de Bacillus thuringiensis var. thuringiensis pentru generația II a gândacului (Leptinotarsa descemlineata) in vederea stabilirii activității biologice a bacteriilor entomopatogene.

Experiențele s-au efectuat pe lotul experimental de cartof soiul „BelaRosa” la Institutul GFPP în șase variante a câte trei repetiții.

Tabelul 1. Eficacitatea biologică a suspensiei entomopatogene de Bacillus thuringiensis în combaterea dăunătorului Leptinotarsa decemlineata, la cartof, soiul „BelaRosa”

\begin{tabular}{|c|c|c|c|c|c|c|c|c|}
\hline \multirow[t]{2}{*}{ Nr. } & \multirow[t]{2}{*}{ Varianta } & \multirow[t]{2}{*}{ Repetiții } & \multirow[t]{2}{*}{ Concentrațiile } & \multirow{2}{*}{$\begin{array}{l}\text { Până } \\
\text { /pre. } \\
\text { larve / } \\
10 \\
\text { plante }\end{array}$} & \multicolumn{3}{|c|}{$\begin{array}{l}\text { După prelucrare } \\
\text { larve/10 plante la ziua }\end{array}$} & \multirow{2}{*}{$\begin{array}{c}\text { Eficacitatea } \\
\text { biologică, } \\
\%\end{array}$} \\
\hline & & & & & 5 & 7 & 9 & \\
\hline \multirow[t]{4}{*}{1.} & Martor & $\mathrm{I}$ & & 104 & 138 & 213 & 264 & 0 \\
\hline & & II & & 100 & 233 & 187 & 220 & 0 \\
\hline & & III & & 123 & 138 & 146 & 179 & 0 \\
\hline & & Media & & 109,0 & 169,6 & 182 & 221 & 0 \\
\hline \multirow[t]{4}{*}{2} & $\begin{array}{l}\text { B. } \\
\text { thuringiensis }\end{array}$ & I & $10^{3}$ & 106 & 106 & 140 & 162 & 0 \\
\hline & & II & & 96 & 200 & 190 & 196 & 0 \\
\hline & & III & & 213 & 101 & 284 & 260 & 0 \\
\hline & & Media & & 138,3 & 203,5 & 204,6 & 206,0 & 0 \\
\hline \multirow[t]{2}{*}{3} & $\begin{array}{l}B . \\
\text { thuringiensis }\end{array}$ & $\mathrm{I}$ & $10^{5}$ & 117 & 71 & 67 & 61 & 47,8 \\
\hline & & II & & 121 & 111 & 98 & 91 & 24,2 \\
\hline
\end{tabular}




\begin{tabular}{|c|c|c|c|c|c|c|c|c|}
\hline & & III & & 122 & 101 & 91 & 86 & 29,5 \\
\hline & & Media & & 120,0 & 94,3 & 85,3 & 79,3 & 33,9 \\
\hline \multirow[t]{4}{*}{4} & $\begin{array}{l}B . \\
\text { thuringiensis }\end{array}$ & I & $10^{7}$ & 114 & 61 & 59 & 58 & 49,1 \\
\hline & & II & & 124 & 68 & 93 & 64 & 48,3 \\
\hline & & III & & 187 & 147 & 128 & 120 & 35,8 \\
\hline & & Media & & 141,6 & 92,3 & 93,0 & 80,6 & 44,4 \\
\hline \multirow[t]{4}{*}{5} & $\begin{array}{l}\text { St.Actara } \\
25 \mathrm{WG}\end{array}$ & I & 0,06 & 125 & 6 & 5 & 4 & 96,8 \\
\hline & & II & & 121 & 0 & 2 & 2 & 99,1 \\
\hline & & III & & 118 & 1 & 0 & 3 & 96,6 \\
\hline & & Media & & 121,3 & 3,1 & 3,1 & 3,0 & 97,5 \\
\hline \multirow[t]{5}{*}{6} & St.BioStar & I & 2,0 & 105 & 136 & 134 & 145 & 0 \\
\hline & & II & & 120 & 135 & 143 & 175 & 0 \\
\hline & & III & & 127 & 131 & 141 & 173 & 0 \\
\hline & & Media & & 117,3 & 134,0 & 139,3 & 164,0 & 0 \\
\hline & DEM & & & & & & & 2,4 \\
\hline
\end{tabular}

Analizând tabelul 1, putem menționa, că eficacitatea biologică a suspensiei entomopatogene de Bacillus thuringiensis în combaterea dăunătorului Leptinotarsa decemlineata, la cartof, soiul „BelaRosa” în condiții de câmp, la concentraţia $10^{5}$ în medie a fost de $33.9 \%$ iar concentrația $10^{7}$ în medie a indicat 44,4\% față de etalonul chimic Actara $25 \mathrm{WG}$, care a avut o eficacitate de $97,5 \%$.

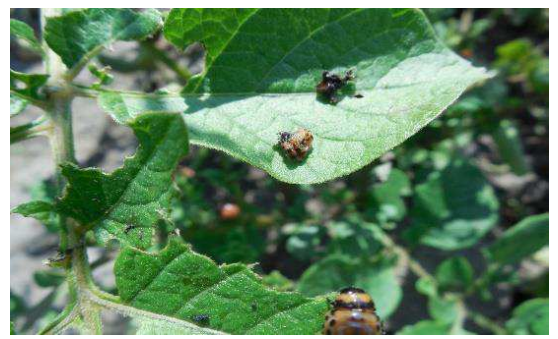

a)

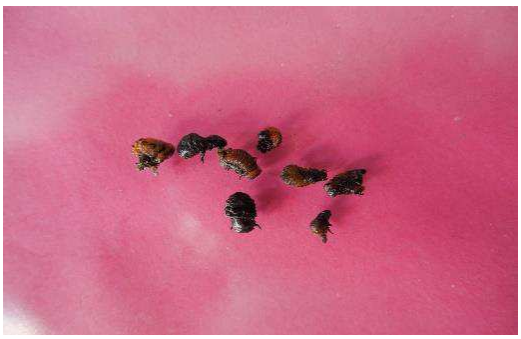

b)

Figura. 1.a,b. Larve infectate de Bacillus thuringiensis după prelucrare

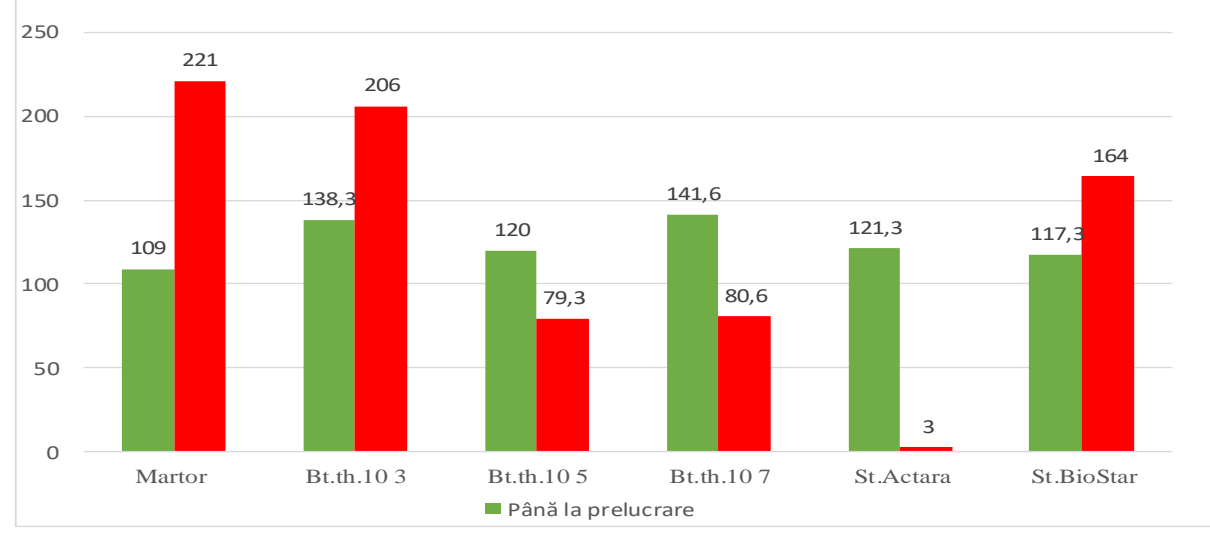

Figura. 2. Graficul dezvoltării larvelor dăunătorului Leptinotarsa decemlineata, la cartof, soiul „BelaRosa” înainte și după prelucrare. 
În figura nr. 2, este redată graficul dezvoltării larvelor dăunătorului Leptinotarsa decemlineata la cartof, soiul „BelaRosa” înainte și după prelucrare. În martor dezvoltarea larvelor s-a majorat de la 109 până la 221 de larve. Iar in varianta Bacillus thuringiensis $10^{7}$ înainte de prelucrare era de 141,6 larve, iar după prelucrare a scăzut până la 80,6 larve.

\section{Concluzii}

Aplicarea biopreparatelor bacteriene în agricultura ecologică manifestă un rol important în combaterea insectelor dăunătoare și în procesul de protejare a solului, faunei de diferite pesticide.

Tulpinile entomopatogene de Bacillus thuringiensis în combaterea dăunătorului Leptinotarsa decemlineata au o eficacitate biologică de $50,0 \%$ in combaterea dăunătorului la cultura de cartof, iar entomofagii Perilius bioculatus, Podizus maculiventris, bugurile Damselbug (Nabis liniatus) care se află pe aceste terenuri rămân vii in comparație cu loturile unde au fost folosite preparate chimice.

Folosirea in sistem ecologic a bacteriilor entomopatogene de Bacillus thuringiensis și a entomofagilor prădători pot sta la baza masurilor eficiente tehnologic pentru înlocuirea preparatelor chimice la culturile legumicole, tehnice și alte culturi.

\section{Bibliografie}

1. Бурцева Л. И. Методы выделения и биотестирования энтомопатогенных бактерий. Патогены насекомых: структурные и функциональные аспекты. [под ред. В.В.Глупова.] / Л. И. Бурцева М., 2001, с.736.

2. Гар К.А. Методы испытания токсичности и эффективности инсектицидов. Москва, 1963, 283 с.

3. Гришечкина С. Д., Ермолова В.П. Сельскохозяйственная биология, СанктПетербург Пушкин,2015, том.50, nr.3, с.361-368.

4. Полякова Е.А. Активизация защитных реакций растений под влиянием метаболитов микроорганизмов. Сборник. «Растение и стресс», 2010, с. 286. 